Review

\title{
Animal models for cutaneous vaccine delivery
}

\author{
Hoang J.H.B. Hirschberg a,*, Elly van Riet ${ }^{a}$, Dinja Oosterhoff ${ }^{a}$, Joke A. Bouwstra ${ }^{\mathrm{b}}$, Gideon F.A. Kersten ${ }^{\mathrm{a}, \mathrm{b}}$ \\ a Institute for Translational Vaccinology, P.O. Box 450, 3720 AL Bilthoven, The Netherlands \\ ${ }^{\mathrm{b}}$ Leiden Academic Centre for Drug Research (LACDR), Leiden University, P.O. Box 9502, 2300 RA Leiden, The Netherlands
}

\section{A R T I C L E I N F O}

\section{Article history:}

Received 28 September 2014

Received in revised form 4 February 2015

Accepted 5 February 2015

Available online 14 February 2015

\section{Keywords:}

Animal models

Vaccine delivery

Skin barrier

Cutaneous

Intradermal

Topical

\begin{abstract}
A B S T R A C T
Main challenges in skin vaccination are overcoming the stratum corneum (SC) barrier and targeting the antigen presenting cells (APC) in the epidermis and the dermis. For this purpose many delivery techniques are being developed. In vivo immunogenicity and safety studies in animals are mandatory before moving to clinical trials. However, the results obtained in animals may or may not be predictive for humans. Knowledge about differences and similarities in skin architecture and immunology within a species and between species is crucial.

In this review, we discuss variables, including skin morphology, skin barrier function, mechanical properties, site of application and immunology, which should be taken into account when designing animal studies for vaccination via the skin in order to support the translation to clinical trial outcomes.
\end{abstract}

(c) 2015 Elsevier B.V. All rights reserved.

\section{Contents}

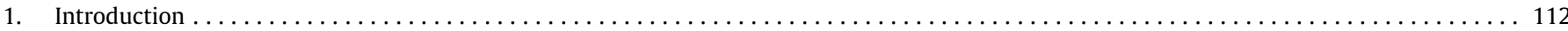

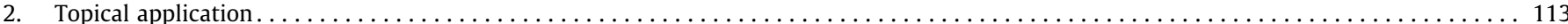

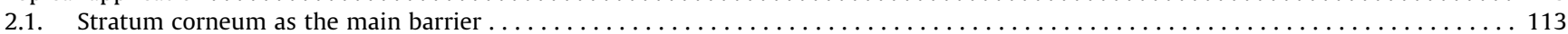

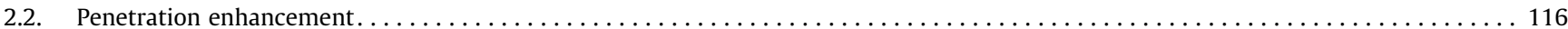

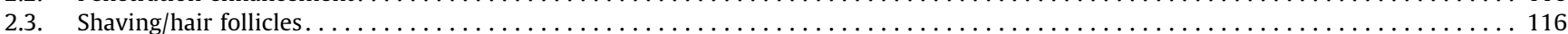

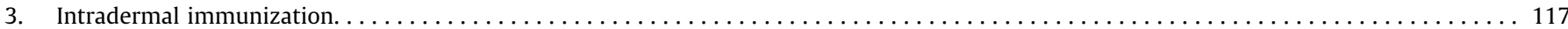

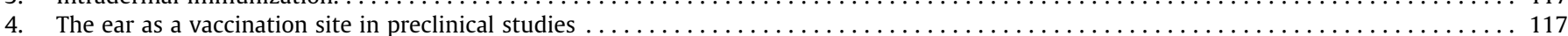

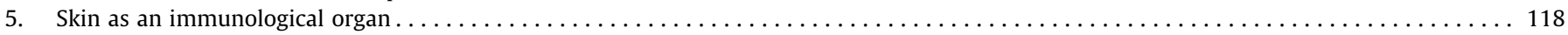

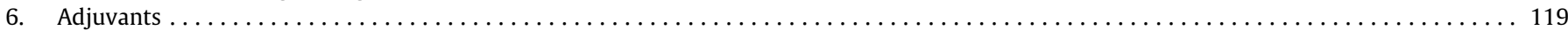

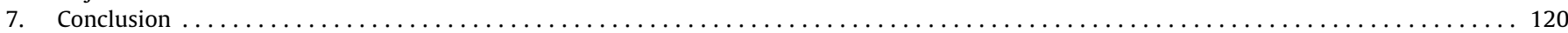

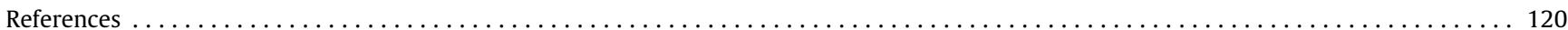

\section{Introduction}

The skin is the largest organ in the body and protects against environmental challenges, such as pathogens, injuries and UV radiation. It harbors many immune cells, making it an attractive site for vaccination. The smallpox vaccine, the first vaccine used and also the most successful, was delivered in the skin, using

\footnotetext{
* Corresponding author at: National Institute for Public Health and the Environment, P.O. Box 1, 3720 BA Bilthoven, The Netherlands.

E-mail addresses: Hoang.Hirschberg@rivm.nl (H.J.H.B. Hirschberg), Elly.van. Riet@Intravacc.nl (E. van Riet), Dinja.Oosterhoff@intravacc.nl (D. Oosterhoff), bouwstra@lacdr.leidenuniv.nl (J.A. Bouwstra), Gideon.Kersten@Intravacc.nl (G.F.A. Kersten).
}

bifurcated needles. Nowadays only three other vaccines are on the market for intradermal delivery: the bacillus Calmette-Guerin (BCG) and rabies vaccine are both administered in the skin using hypodermic needles and since 2009, an influenza vaccine was reformulated for use in a novel microinjection system (BD Soluvia $^{\mathrm{TM}}$ ). This system enables medical personnel to inject the vaccine intradermally on a more reliable and consistent manner.

Regulations require that immunogenicity and safety of vaccines is first determined in animal models before entering clinical trials. The results of animal studies are difficult to extrapolate to the human situation. This is especially true for cutaneous vaccines. For this reason the risk of failure of clinical studies is high. 
An example is the development of a cutaneous vaccine patch against travelers diarrhea. The vaccine contains heat-labile enterotoxin (LT) from Enterotoxinogenic Escherichia coli (ETEC), an important causative agent of travelers diarrhea. Preclinical studies in mice immunized with LT applied on intact skin demonstrated very high anti-LT titers and full protection against lethal systemic challenge with the toxin (Beignon et al., 2001; Glenn et al., 1998). In a first clinical trial (Glenn et al., 2000) on intact skin, IgG titers were induced but responses were not as high as in preclinical trials. In following clinical trials (Behrens et al., 2014; Steffen et al., 2013), the investigators applied an abrasion step before vaccine application to reduce the skin barrier function. Although the delivery of LT in the skin was demonstrated, antibody titers remained much lower than in mice studies and the antibody titers were not protective.

Knowledge about differences in skin architecture and skin immunology between different species and within species is crucial in order to understand the limitations of skin immunization in experimental animals with respect to the situation in humans. For cutaneous vaccination, the difference in epidermis (especially stratum corneum) and dermis thickness is an additional challenge in the translation of animals to human. In this review, we discuss variables between animal species used to test cutaneous vaccines, some of which can be controlled by the investigator and which should be considered in the translation of animal-clinical studies of vaccines delivered via the skin.

The skin is composed of three layers: the epidermis, the dermis and the subcutis. The viable epidermis is composed of mainly keratinocytes (90\%). The other $10 \%$ of the cells are represented by Langerhans Cells (LC), melanocytes and mast cells. Keratinocytes differentiate in the epidermis and during the differentiation, the cells move to the upper layer of the viable epidermis. Terminally differentiated keratinocytes are called corneocytes (dead cells), which form the surface layer of the skin, the stratum corneum (SC). This SC forms the main barrier for water loss from the body (inside-out diffusion) and for invading pathogens from the environment (outside-in diffusion). The dermis is located underneath the epidermis and is composed of dense fibroelastic connective tissue with lymph vessels, nerves, sebaceous glands, sweat glands and hair follicles. The cells present in the dermis are fibroblasts, dermal dendritic cells (dDC), mast cells, monocytes and macrophages. The subcutis is the deepest layer of the skin and is composed of mainly fat tissue.

Cutaneous vaccination delivers the vaccine either onto the SC, or deeper in the skin, in the epidermis or the dermis. In literature, there is a variety in definitions for vaccination into or onto the skin. In this review, we will use the terms "topical vaccination", "intradermal vaccination” and "cutaneous vaccination” (Table 1 ).
With topical application, the vaccine is applied onto intact skin or pre-treated skin. The vaccine formulation diffuses through (a part of) the SC, into the epidermis and the dermis. With intradermal delivery, the SC diffusion is circumvented by for example needle injections, liquid or solid jet injections, or microneedle insertion. With intradermal vaccination, the vaccine is delivered directly into the epidermis or the dermis. Cutaneous vaccination will be used to assign both topical and intradermal application.

\section{Topical application}

\subsection{Stratum corneum as the main barrier}

The main challenge of topical applications is the passage through the SC in a consistent way such that a substantial part of the antigen dose is delivered to the immune cells. The SC is composed of corneocytes (dead keratinocytes) and intercellular lipids, arranged in a brick and mortar structure, composed of corneocytes and lipids, respectively. This structure forms a barrier against invading pathogens. Topically applied vaccine formulations have to penetrate through this SC in order to reach the immune cells in the epidermis and the dermis. The thicker the SC, the longer the diffusion pathway for penetrating substances. Body sites with thinner SC would therefore be more appropriate for topical application. The thickness of skin (epidermis + dermis) is subject of many studies. However, data specifically on SC thickness is limited. SC thickness in animals is measured by using microscopic techniques on biopsy samples prepared by conventional formalinparaffin processing or by cryo techniques. Formalin-paraffin processing distorts the skin morphology caused by swelling and shrinking and often results in a basket-wave appearance of the SC. This artefact makes thickness quantification a difficult task. Cryo-preparation techniques cause minimal structural changes of the sample. Boundaries between viable epidermis and SC in biopsy samples might be difficult to determine resulting in less accurate measurements. Monteiro-Riviere et al. compared the SC and viable epidermis thickness at 5 body sites in 8 animal species, by paraffin sections and frozen sections (Monteiro-Riviere et al., 1990). A selection of their data is presented in Table 2. The two methods showed significantly different results with smaller SC thickness with paraffin sections as compared to frozen sections. With the frozen section method, for some body sites relatively thick SC was found, sometimes even comparable to the viable epidermis thicknesses (SC of ear of rats is $8.49 \mu \mathrm{m}$; viable epidermis is $8.8 \mu \mathrm{m}$ ). This was confirmed by Bronaugh et al. (1983) and Sato et al. (1991). In these sections, the boundaries between viable epidermis and SC in biopsy samples might be difficult to define which may cause the large differences between the two methods when

Table 1

Definition of terminology used in this review.

\begin{tabular}{|c|c|c|}
\hline & Delivery site of vaccine & Delivery techniques \\
\hline Topical application & Onto intact SC or partly removed or altered SC & $\begin{array}{l}\text { Skin patches, sometimes in combination with pre-treatment of the skin by: } \\
\text { - Emery paper } \\
\text { - Tape stripping } \\
\text { - Electroporation } \\
\text { - Ultrasound } \\
\text { - Hydration, permeation enhancers } \\
\text { - Microneedle pre-treatment }\end{array}$ \\
\hline Intradermal application & In epidermis or dermis & $\begin{array}{l}\text { - Microneedles (coated, hollow, dissolving) } \\
\text { - Fluid Jet injections } \\
\text { - Powder jet injections } \\
\text { - Needle and syringe injections } \\
\text { - Invasive electroporation } \\
\text { - Tattooing }\end{array}$ \\
\hline Cutaneous application & Onto SC or in epidermis or dermis & \\
\hline
\end{tabular}


Table 2

Effect of skin biopsy preparation method on apparent SC thickness. SC thickness (mean and standard error) in different species and different sites.

\begin{tabular}{|c|c|c|c|c|c|c|}
\hline Species & Site & $\mathrm{SC}(\mu \mathrm{m})$ & Viable epidermis & Epidermis $(\mu \mathrm{m})$ & Method & Ref. \\
\hline Mouse & $\begin{array}{l}\text { Back } \\
\text { Buttock } \\
\text { Ear } \\
\text { Abdomen }\end{array}$ & $\begin{aligned} 5.8 & \pm 0.3 \\
6.26 & \pm 0.44 \\
2.9 & \pm 0.12 \\
4.4 & \pm 0.44 \\
2.78 & \pm 0.27 \\
9.73 & \pm 1.23 \\
5.56 & \pm 0.71 \\
7.3 & \pm 2.69 \\
3.01 & \pm 0.3\end{aligned}$ & $\begin{aligned} 9.04 & \pm 0.88 \\
13.32 & \pm 1.19 \\
6.95 & \pm 0.6 \\
9.09 & \pm 0.66 \\
12.05 & \pm 1.36 \\
14.19 & \pm 1.34 \\
10.43 & \pm 1.16 \\
9.73 & \pm 2.28\end{aligned}$ & $\begin{aligned} 12.6 & \pm 0.8 \\
15.3 & \pm 0.98^{\mathrm{a}} \\
16.22 & \pm 1.20^{\mathrm{a}} \\
11.35 & \pm 0.74^{\mathrm{a}} \\
11.87 & \pm 0.71^{\mathrm{a}} \\
21.78 & \pm 1.83^{\mathrm{a}} \\
19.75 & \pm 1.52^{\mathrm{a}} \\
17.73 & \pm 2.93^{\mathrm{a}} \\
12.74 & \pm 2.30^{\mathrm{a}}\end{aligned}$ & $\begin{array}{l}\text { Frozen section } \\
\text { Frozen section } \\
\text { Paraffin section } \\
\text { Frozen section } \\
\text { Paraffin section } \\
\text { Frozen section } \\
\text { Paraffin section } \\
\text { Frozen section } \\
\text { Paraffin section }\end{array}$ & $\begin{array}{l}\text { Bronaugh et al. (1982) } \\
\text { Monteiro-Riviere et al. (1990) } \\
\text { Monteiro-Riviere et al. (1990) } \\
\text { Monteiro-Riviere et al. (1990) } \\
\text { Monteiro-Riviere et al., 1990 } \\
\text { Monteiro-Riviere et al. (1990) } \\
\text { Monteiro-Riviere et al., 1990 } \\
\text { Monteiro-Riviere et al. (1990) } \\
\text { Monteiro-Riviere et al. (1990) }\end{array}$ \\
\hline Hairless mouse & Back & $\begin{array}{l}8.8 \pm 1.0 \\
8.9 \pm 0.4\end{array}$ & & $\begin{array}{r}18 \pm 1.5 \\
28.6 \pm 0.9\end{array}$ & $\begin{array}{l}\text { Frozen section } \\
\text { Frozen section }\end{array}$ & $\begin{array}{l}\text { Sato et al. (1991) } \\
\text { Bronaugh et al. (1982) }\end{array}$ \\
\hline Rat & $\begin{array}{l}\text { Back female } \\
\text { Back male } \\
\text { Back } \\
\text { Abdomen female } \\
\text { Abdomen male } \\
\text { Abdomen } \\
\text { Buttock } \\
\text { Ear }\end{array}$ & $\begin{aligned} 18.4 & \pm 0.5 \\
18.2 & \pm 0.1 \\
34.7 & \pm 2.3 \\
12.31 & \pm 1.68 \\
5 & \pm 0.85 \\
13.7 & \pm 0.6 \\
13.8 & \pm 0.7 \\
6.02 & \pm 1.10 \\
4.56 & \pm 0.61 \\
13.34 & \pm 1.26 \\
4.09 & \pm 0.27 \\
8.49 & \pm 0.97 \\
3.63 & \pm 0.4\end{aligned}$ & $\begin{array}{r} \\
9.53 \pm 1.6 \\
21.66 \pm 2.23 \\
\\
9.27 \pm 0.66 \\
11.58 \pm 1.02 \\
13.71 \pm 3.91 \\
15.52 \pm 1.02 \\
8.8 \pm 0.95 \\
13.48 \pm 1.24\end{array}$ & $\begin{aligned} 32,1 & \pm 1,3 \\
31.2 & \pm 1.5 \\
61.1 & \pm 3.0 \\
21.84 & \pm 2.32^{\mathrm{a}} \\
26.66 & \pm 2.39^{\mathrm{a}} \\
34.8 & \pm 1.81 \\
30.4 & \pm 1.5 \\
15.29 & \pm 1.28^{\mathrm{a}} \\
16.14 & \pm 1.19^{\mathrm{a}} \\
27.05 & \pm 4.11^{\mathrm{a}} \\
19.61 & \pm 1.06^{\mathrm{a}} \\
17.29 & \pm 1.36^{\mathrm{a}} \\
17.11 & \pm 1.30^{\mathrm{a}}\end{aligned}$ & $\begin{array}{l}\text { Frozen section } \\
\text { Frozen section } \\
\text { Frozen section } \\
\text { Frozen section } \\
\text { Paraffin section } \\
\text { Frozen section } \\
\text { Frozen section } \\
\text { Frozen section } \\
\text { Paraffin section } \\
\text { Frozen section } \\
\text { Paraffin section } \\
\text { Frozen section } \\
\text { Paraffin section }\end{array}$ & $\begin{array}{l}\text { Bronaugh et al., } 1982 \\
\text { Bronaugh et al. } \\
\text { Bronaugh et al. (1983) } \\
\text { Monteiro-Riviere et al., 1990 } \\
\text { Monteiro-Riviere et al. (1990) } \\
\text { Bronaugh et al., 1983 } \\
\text { Bronaugh et al. (1983) } \\
\text { Monteiro-Riviere et al. (1990) } \\
\text { Monteiro-Riviere et al. (1990) } \\
\text { Monteiro-Riviere et al. (1990) } \\
\text { Monteiro-Riviere et al. (1990) } \\
\text { Monteiro-Riviere et al. (1990) } \\
\text { Monteiro-Riviere et al. (1990) }\end{array}$ \\
\hline Hairless rats & Abdomen & $15.4 \pm 3.3$ & & $23.8 \pm 5.3$ & Frozen section & Sato et al. (1991) \\
\hline Pig & $\begin{array}{l}\text { Abdomen } \\
\text { Buttock } \\
\text { Ear }\end{array}$ & $\begin{array}{r}17.5 \pm 2.4 \\
15.06 \pm 0.63 \\
12.28 \pm 0.72 \\
15.29 \pm 1.14 \\
14.9 \pm 1.91 \\
18.07 \pm 1.82 \\
12.01 \pm 0.95 \\
17-28 \\
13.13 \pm 1.8 \\
9.88 \pm 1.16 \\
26.4 \pm 0.4\end{array}$ & $\begin{array}{l}41.55 \pm 1.94 \\
51.89 \pm 1.49 \\
30.58 \pm 1.62 \\
46.76 \pm 2.01 \\
46.02 \pm 3.8 \\
56.68 \pm 3.08 \\
60-85 \\
44.63 \pm 4.26 \\
51.43 \pm 9.05\end{array}$ & $\begin{array}{c}50.7 \pm 11.4 \\
56.61 \pm 2.04^{\mathrm{a}} \\
64.17 \pm 1.65^{\mathrm{a}} \\
45.87 \pm 1.98^{\mathrm{a}} \\
61.66 \pm 2.77^{\mathrm{a}} \\
64.09 \pm 4.21^{\mathrm{a}} \\
68.69 \pm 3.22^{\mathrm{a}} \\
77-113 \\
57.76 \pm 4.62^{\mathrm{a}} \\
61.31 \pm 9.12^{\mathrm{a}} \\
65.8 \pm 1.8\end{array}$ & $\begin{array}{l}\text { Frozen section } \\
\text { Frozen section } \\
\text { Paraffin section } \\
\text { Frozen section } \\
\text { Paraffin section } \\
\text { Frozen section } \\
\text { Paraffin section } \\
\text { Frozen section } \\
\text { Frozen section } \\
\text { Paraffin section } \\
\text { Frozen section }\end{array}$ & $\begin{array}{l}\text { Sato et al. (1991) } \\
\text { Monteiro-Riviere et al. (1990) } \\
\text { Monteiro-Riviere et al. (1990) } \\
\text { Monteiro-Riviere et al., 1990 } \\
\text { Monteiro-Riviere et al. (1990) } \\
\text { Monteiro-Riviere et al. (1990) } \\
\text { Monteiro-Riviere et al. (1990) } \\
\text { Jacobi et al. (2007) } \\
\text { Monteiro-Riviere et al. (1990) } \\
\text { Monteiro-Riviere et al. (1990) } \\
\text { Bronaugh et al. (1982) }\end{array}$ \\
\hline
\end{tabular}

(?) Site is unknown.

${ }^{\text {a }}$ Calculated epidermis value $=$ SC + viable epidermis.

considering the SC and the viable epidermis thickness separately. This is confirmed by the sum of the viable epidermis thickness and the SC thickness, which results in a calculated total epidermis thickness (viable epidermis + SC). This calculated total epidermis thickness is comparable for the two methods.

Using the same techniques, the study showed significant differences between the same site in different species but for some species also between different anatomical sites within a species (Table 2). The SC of the back of rats as measured with the frozen sections is a factor 2 thicker than the SC of the abdomen. This was confirmed by Bronaugh et al. (1983) for male rats (Table 2). In this latter study a considerable difference in SC thickness of the back of rats was also observed between gender (Bronaugh et al., 1983). The SC of the back of male rats $(34.7 \pm 2.3 \mu \mathrm{m})$ is twice as thick as the back of female rats $(18.2 \pm 1.0 \mu \mathrm{m})$. No difference between gender was found for the abdominal SC thickness. In the same study permeability experiments with benzoic acid showed a difference in absorption between back and abdominal skin of the male rat and a sex-related absorption difference through back skin. The absorption increased with decreasing SC thickness. These findings are of considerable importance since topical application in rats (and mice) is mostly done on the abdomen or the back because of the available large surface area. In male rats, the choice between abdomen and back might influence the absorption of the topically applied formulation.

For SC thickness in humans, more data is available as compared to animals. A summary of human SC thickness reported in literature is provided in Table 3. For humans, non-invasive methods have also been used to measure the SC in vivo. Examples are confocal laser microscopy, confocal raman spectroscopy (Bohling et al., 2014; Egawa et al., 2007) confocal reflectance microscopy (Huzaira et al., 2001; Robertson and Rees, 2010) and ultrasound echoscopy (Ploin et al., 2011). The advantage of these techniques is that no biopsies and no skin preparation is needed. It should be kept in mind that some of these techniques only give an estimation of the SC thickness because boundaries between SC and viable epidermis are difficult to define and the depth resolution might be limited. A technique such as Raman spectroscopy measures a "stratum corneum apparent thickness", which include the upper part of the stratum granulosum in addition to the SC (Egawa et al., 2007). The different techniques result in a wide value range of SC thicknesses. In literature, SC thickness of the forearm from 5 to $40 \mu \mathrm{m}$ (Agache et al., 2004; Robertson and Rees, 2010) and of the abdomen from 6 to $17 \mu \mathrm{m}$ (Holbrook and Odland, 1974; Robertson and Rees, 2010) are published. Absolute values obtained with different techniques can therefore not be compared from one study to another. Within one study, using the same technique, SC thicknesses can be compared. Beside the different techniques, measuring conditions (skin hydration will lead to increased skin thickness as it can absorb around $300 \%$ of its dry weight (Bouwstra et al., 2003)), skin conditions (i.e. UV exposure) and environmental conditions (i.e. humidity) can also contribute to the variation in SC thickness. Differences in SC thickness are considerable at different body sites but vary less between individuals (Egawa et al., 2007; Sandby-Moller et al., 2003). 
Table 3

SC thickness measured with different techniques in humans at various body sites.

\begin{tabular}{|c|c|c|c|c|c|}
\hline & $\mathrm{SC}(\mu \mathrm{m})$ & Viable epidermis $(\mu \mathrm{m})$ & Epidermis $(\mu \mathrm{m})$ & Measuring technique & Lit. \\
\hline Chest & $\begin{array}{l}18.2 \pm 3.3 \\
6.5\end{array}$ & & 56 & $\begin{array}{l}\text { Frozen section } \\
\text { Reflectance confocal microscopy }\end{array}$ & $\begin{array}{l}\text { Sato et al. (1991) } \\
\text { Robertson and Rees (2010) }\end{array}$ \\
\hline Forearm & $\begin{array}{l}19.5 \pm 2.8 \\
18.3 \pm 4.9 \\
22.6 \pm 4.33\end{array}$ & $56.6 \pm 11.5$ & $74.9 \pm 12.7(*)$ & $\begin{array}{l}\text { Confocal raman spectroscopy } \\
\text { Frozen section } \\
\text { Raman spectroscopy }\end{array}$ & $\begin{array}{l}\text { Bohling et al. (2014) } \\
\text { Sandby-Moller et al. (2003) } \\
\text { Egawa et al. (2007) }\end{array}$ \\
\hline $\begin{array}{l}\text { Outer forearm } \\
\text { Inner forearm }\end{array}$ & $\begin{array}{l}10.9 \\
6.2 \\
8.1-16.2\end{array}$ & & $\begin{array}{l}60.3 \\
59.4\end{array}$ & $\begin{array}{l}\text { Reflectance confocal microscopy } \\
\text { Reflectance confocal microscopy } \\
\text { Frozen section }\end{array}$ & $\begin{array}{l}\text { Robertson and Rees (2010) } \\
\text { Robertson and Rees (2010) } \\
\text { Holbrook and Odland (1974) }\end{array}$ \\
\hline $\begin{array}{l}\text { Forearm } 23 \text { years } \\
\text { Forearm } 47 \text { years } \\
\text { Forearm } 72 \text { years }\end{array}$ & $\begin{array}{l}18 \\
16 \\
25\end{array}$ & $\begin{array}{l}57 \\
48 \\
49\end{array}$ & $\begin{array}{l}73 \\
64 \\
73\end{array}$ & $\begin{array}{l}\text { Multiphoton laser tomography } \\
\text { Multiphoton laser tomography } \\
\text { Multiphoton laser tomography }\end{array}$ & $\begin{array}{l}\text { Koehler et al. (2010) } \\
\text { Koehler et al. (2010) } \\
\text { Koehler et al. (2010) }\end{array}$ \\
\hline $\begin{array}{l}\text { Inner upperarm } \\
\text { Upper arm }\end{array}$ & $\begin{array}{l}6.4 \\
21.8 \pm 3.63\end{array}$ & & 58.2 & $\begin{array}{l}\text { Reflectance confocal microscopy } \\
\text { Raman spectroscopy }\end{array}$ & $\begin{array}{l}\text { Robertson and Rees (2010) } \\
\text { Egawa et al. (2007) }\end{array}$ \\
\hline Palm & $\begin{array}{l}208.8 \pm 41.7 \\
173 \pm 36.96\end{array}$ & & & $\begin{array}{l}\text { Confocal raman spectroscopy } \\
\text { Raman spectroscopy }\end{array}$ & $\begin{array}{l}\text { Bohling et al., } 2014 \\
\text { Egawa et al. (2007) }\end{array}$ \\
\hline Cheek & $\begin{array}{l}12.8 \pm 1.5 \\
16.8 \pm 2.84\end{array}$ & & & $\begin{array}{l}\text { Confocal raman spectroscopy } \\
\text { Raman spectroscopy }\end{array}$ & $\begin{array}{l}\text { Bohling et al. (2014) } \\
\text { Bohling et al. (2014) }\end{array}$ \\
\hline Abdomen & $\begin{array}{l}6.3 \\
6.9-9.8 \\
16.8 \pm 0.7\end{array}$ & & $\begin{array}{l}61.3 \\
46.9 \pm 2.3\end{array}$ & $\begin{array}{l}\text { Reflectance confocal microscopy } \\
\text { Frozen section } \\
\text { Frozen section }\end{array}$ & $\begin{array}{l}\text { Robertson and Rees (2010) } \\
\text { Holbrook and Odland (1974) } \\
\text { Bronaugh et al. (1982) }\end{array}$ \\
\hline Buttock & $14.9 \pm 3.4$ & $81.5 \pm 15.7$ & $96.5 \pm 16.1(*)$ & Frozen section & Sandby-Moller et al. (2003) \\
\hline Back & $\begin{array}{l}8.4 \\
8.2-11.3\end{array}$ & & 55.6 & $\begin{array}{l}\text { Reflectance confocal microscopy } \\
\text { Frozen section }\end{array}$ & $\begin{array}{l}\text { Robertson and Rees (2010) } \\
\text { Holbrook and Odland (1974) }\end{array}$ \\
\hline Shoulder & $11.0 \pm 2.2$ & $70.3 \pm 13.6$ & $81.3 \pm 13.5(*)$ & Frozen section & Sandby-Moller et al. (2003) \\
\hline
\end{tabular}

Obvious sites for topical application of vaccines in human are the abdomen (Beignon et al., 2001), the back, the deltoid/upper arm (Behrens et al., 2014) or the forearm (Etchart et al., 2007). Several studies suggest, based on absorption measurements, a more resistant barrier of the skin of the forearm as compared to the skin of the abdomen or back (Holbrook and Odland, 1974). As shown in Table 3, the forearm has a thicker SC as compared to the abdomen or the upper arm. This suggests that body sites such as upper arm, thigh, abdomen and back are likely most effective sites for topical application in humans.

Many vaccines (e.g. vaccines of childhood vaccination programs, influenza vaccine) are licensed for a selective age range. Therefore SC thickness and structure as function of age should be considered. Several groups reported that SC thickness is independent of age in the range of 20-68 years (Koehler et al., 2010; Sandby-Moller et al., 2003). This was confirmed by Fairley and Rasmussen (1983) for the range of 3 month-46 years. More recent reports showed however a thinner SC for infants (3-12 months) as compared to adults (Fluhr et al., 2014; Nikolovski et al., 2008). Nikolovski et al. (2008) showed with TEWL (Trans Epidermal Water Loss) measurements, that the skin barrier function of infants younger than 1 year is more permeable than adult skin. Fluhr et al. (2014) showed structural differences between infant SC and adult SC: neonates and 5-6 weeks old children had a less organized surface anatomy than older children groups and adults. These structural differences might influence the barrier function of the skin. A successful topical application for very young children ( $<1$ year) might therefore not work on adult skin. Consequently, for translation studies, different animals or site of application might be needed in preclinical studies depending on the target group.

In many papers, a single value of SC thickness is given without specification of body site. These values are probably not calculated averages but rather isolated measurements of a specific site. One has to be aware of this when using a SC thickness value from literature for e.g. interspecies comparisons. From the available laboratory animals, the skin of pigs is reported to resemble most that of humans (Simon and Maibach, 2000). In one study, Sato et al. (1991) compared the SC thickness of 6 different species (microscopy of cryo-prepared sections). The results for mice, rats, pigs and humans are shown in Table 2. In this study it was confirmed that at the measured sites, the pig SC thickness indeed resembles human SC thickness most. The SC thickness of the abdomen of hairless rats showed however also comparable SC thickness. Beside the SC thickness, the number of cell layers in the SC is also comparable in humans and pigs. The SC of humans (Bouwstra et al., 2003; Holbrook and Odland, 1974) and pigs (Swindle, 2008) is composed of 10-15 cell layers whereas mice have only approximately 6 cell layers (Rissmann et al., 2009).

Apart from thickness of the SC, the intercellular lipids play a key role in the skin barrier function. The SC lipids are organized in two characteristic crystalline lamellar structures with repeat distances of approximately $13 \mathrm{~nm}$ and $6 \mathrm{~nm}$. The $13 \mathrm{~nm}$ lamellar phase is more effective in creating an effective skin barrier function than the $6 \mathrm{~nm}$ lamellar phase (de Jager et al., 2006). Both phases are present in human and pigs (Bouwstra et al., 1995, 1991) whereas in mice the $13 \mathrm{~nm}$ phase is abundantly present (Bouwstra et al., 1994). The packing of the lipids, that is the lipid organization within the lamellae, also contribute to the barrier function. A dense orthorhombic organization results in a lower permeability than a hexagonal gel phase or the less dense disordered liquid phase (van Smeden et al., 2014). In human and mouse SC, lipids form mainly an orthorhombic structures, while in pig SC mainly a hexagonal packing is present (Caussin et al., 2008). As both the $13 \mathrm{~nm}$ lamellar phase and the orthorhombic lateral packing are abundantly present in mouse SC, the higher SC permeability in mice cannot be attributed to the differences in lipid organization. Therefore, the increased permeability in mouse skin may be due to a reduced SC thickness, an increased follicular density (see below), a lower number of cell layers in the SC or a reduced overlap in corneocyte stacking. 


\subsection{Penetration enhancement}

Sufficient penetration through the SC to obtain a therapeutic effect was thought to be limited to molecules smaller than $500 \mathrm{Da}$ (Bos and Meinardi, 2000). This was based on penetration studies with small drug molecules with the target being either the systemic circulation or the dermis. However, Glenn et al. (1998, 1999a,b) showed with a variety of vaccine antigens and adjuvants, which exceed by far the $500 \mathrm{Da}$ limit, that potent immune responses can be induced upon topical application on hydrated skin. In studies with topically applied LT, with a molecular weight of $\sim 85 \mathrm{kDa}$, and tetanus antigen, protective antibody responses were induced in mice. However, mice SC is thinner and has less cell layers than human SC and therefore antigen penetration through human skin may be less efficient. In additional studies topical application of protein antigens on intact skin was shown to be feasible: Scharton-Kersten et al. applied several antigens on untreated mouse skin and induced antibody responses that were sometimes comparable to the intramuscular (i.m) injection (Scharton-Kersten et al., 1999). However, other groups obtained no or poor immune responses upon topical application of antigen on intact skin (Ding et al., 2009b; Glenn et al., 1999a). Therefore, pretreatment of the skin, with e.g. abrasion with emery paper or tape stripping, to enhance SC permeation is applied. Chemical penetration enhancers such as water, alcohols, glycols and surfactants can also enhance penetration through the SC. These molecules increase permeability by distortion of the SC lipid structure or by increasing the solubility of the active in the SC (Benson, 2005; Chantasart and Li, 2012; Lane, 2013; Williams and Barry, 1992). Chemical penetration enhancers are difficult to combine with vaccine antigens. They may have a poor solubility and stability may be affected. Also, the enhancing effect for large compounds, such as vaccine antigens, is limited. Therefore, chemical enhancers are not often used in combination with vaccines. Moghadam et al. (2013) analyzed, in vitro on human skin, the suitability of several chemical enhancers for the absorption of IFN- $\alpha$ (19 $\mathrm{kDa})$. In $1 \%(\mathrm{w} / \mathrm{v}$ in water), Tween-80 the protein was stable and a permeation enhancement of a factor 6 was achieved. Hammond et al. showed in mice an increase in antibody response against CT when the skin was pre-treated with a combination of glycerol and isopropanol (Hammond et al., 2001a). Some detergents are known to have penetration enhancement effects on skin and are compatible with some protein antigens and would be suitable in vaccine formulations. Their penetration enhancement effect has not yet been tested on human skin when combined with antigens, but it is expected that the increased penetration will not be sufficient for these large molecules to penetrate the skin in a reasonable contact time and achieve a therapeutic effect, since doses in the microgram range are usually needed for vaccination.

Apart from molecular excipients, vesicular systems composed of lipids and/or surfactants such as Transfersomes ${ }^{\circledR}$ and elastic vesicles can act as either carriers of entrapped substances or as penetration enhancers (Cevc and Blume, 1992; Cevc et al., 2002; Foldvari et al., 1990; Honeywell-Nguyen et al., 2003; Mezei and Gulasekharam, 1980). Transfersomes ${ }^{\circledR}$ and elastic vesicles are deformable vesicles and their components or the vesicles themselves are reported to penetrate into the SC and subsequently alter the SC intercellular lipid structure. Gupta et al. (2005a) showed higher antibody responses with tetanus toxoid containing transfersomes as compared to conventional liposomes upon topical application with the same antigen dose. The entrapment efficiency of tetanus toxoid in the vesicles was measured and by centrifugational separation of the vesicles and free antigen. Transfersomes revealed significantly higher entrapment efficiency (73\%) in comparison to liposomes (42\%). Vesicle structures for topical application of vaccines have only been tested in animal studies (Gupta et al., 2005a, 2005b; Mishra et al., 2006).

\subsection{Shaving/hair follicles}

The transfollicular pathway is an alternative pathway for non-invasive cutaneous vaccination, avoiding passage through the SC mortar and brick network. In all mammals, hair follicles are, depending on hair type and body region, more or less deeply located in the skin. They are anchored in the dermis but can also penetrate through the dermis into the hypodermis. The hair follicle is covered along its total length by follicle sheaths (Meyer, 2009). The follicular sheaths on the one hand increase the surface area and depth into the epidermis and on the other hand, the hair follicles constitute a reservoir for topically applied substances. This may contribute to a better absorption into the epidermis. Moreover, the environment of the hair follicular duct represents a powerful immunological milieu with LCs along the epidermal sheath.

Using liposomes Jung et al. (2006) performed experiments on pig ear skin because the hair follicle density corresponds well with the hair follicle density on the human back and chest. They prepared liposomes $(200-400 \mathrm{~nm})$ incorporating fluorescent dyes and the penetration depth was measured by laser scanning microscopy in histological sections. They showed that positive charged liposomes and very weak negative charged liposomes have the highest efficacy of follicular penetration.

Fan et al. (1999) applied hepatitis B naked DNA topically on skin of normal mice and nude mice. They showed that fluorescence labeled plasmids were absorbed into the hair follicles and that the presence of intact hair follicles is required for topical application. Mahe et al. (2009) demonstrated that fluorescent polystyrene nanoparticles and Vaccinia virus expressing green-fluorescent protein (MVA-eGFP), after topical application on mouse skin, penetrated via hair follicle openings and translocated into the viable tissue, where they were internalized by skin APCs. The applied MVA-eGFP particles induced strong cellular responses (CD4 and CD8). With confocal microscopy, it was shown that the nanoparticles migrated, most likely in association with migrating APCs, to the lymph nodes. Penetration and transport was more efficient with $40 \mathrm{~nm}$ particles than with $200 \mathrm{~nm}$ particles. The more efficient penetration of $40 \mathrm{~nm}$ particles via hair follicles was also demonstrated by Vogt et al. They showed, that transcutaneously applied $40 \mathrm{~nm}$ fluorescent labeled nanoparticles, but not 750 or $1500 \mathrm{~nm}$, penetrated the dermis of human skin and entered epidermal dendritic cells in vitro (Vogt et al., 2006).

In a phase I clinical study (Combadiere et al., 2010), cyanoacrylate skin surface stripping (CSSS) was used to pre-treat the skin on the upper arm. With this stripping method, approximately $30 \%$ of the stratum corneum is removed, inducing mild barrier disruption and cellular debris from hair follicles are removed, thereby increasing the number of hair follicles available for penetration. Topical application of an influenza vaccine resulted in a superior CD4 and CD8 T cell responses in healthy volunteers and HIV-infected patients, as compared to the i.m route, using the same dose. However, neutralizing antibodies were only induced after i.m injection and not by topical application. Nevertheless, this study demonstrated that penetration through hair follicles in humans is an alternative vaccination route by which cellular responses can be induced. Although in this study, the procedure was painless and well tolerated by the participants, this study was performed with a small cohort $(n=12)$, and the question remains whether this method is really painless and well tolerated when using a larger cohort including participants with varying degrees of body hair densities.

The differences in hair densities between animals and humans should be considered in animal-human translating studies of 
topically applied vaccines. Human and pigs have a sparse follicular density (average 14-30 hair follicles/ $\mathrm{cm}^{2}$ on the back) compared to rats and mice (average 290 hair follicles $/ \mathrm{cm}^{2}$ ) (Monteiro-Riviere, 2010; Swindle, 2008). An important difference in the experimental setup between animal and human studies, which is related to the difference in hair density, is the shaving procedure in animal experiments. For topical application, the skin of animals is shaved $24 \mathrm{~h}$ to $48 \mathrm{~h}$ before application whereas in clinical trials, this step is lacking. Shaving bears a risk that irritation and wounds can affect the immune response. Although the skin is always checked for irritations and wounds, the shaving process is a stress factor that could influence the immune reaction. Ruutu et al. showed that stress factors such as mechanical stimulus to skin achieved by a simple application of a flat metal plate was enough to create a temporary depletion of LCs resulting in a significantly impaired immune response (Ruutu et al., 2011).

\section{Intradermal immunization}

With intradermal immunization, the vaccine formulation is delivered directly in the viable epidermis or the dermis. Consistent intradermal immunization with conventional needles is technically difficult to perform. A lot of effort is put in the development of easyto-handle intradermal devices, preferably without the use of needles, that allow consistent delivery. Jet injectors are gas- or spring powered needle-free devices that deliver liquids or powders at high velocity. The power of the device and, in the case of powders, the mass and size of the particles, determine how deep the formulation is delivered. Needle based devices consist of minineedles and microneedles. The most recently registered intradermal vaccine (Intanza, influenza vaccine) is delivered with the Soluvia microinjection system of $\mathrm{BD}$. This is a single injection system with a 30 gauge, short bevel minineedle of $1.5 \mathrm{~mm}$, which allows relatively easy and reliable intradermal delivery. Microneedles and microneedle patches (Kim et al., 2012; Kommareddy et al., 2013; Koutsonanos et al., 2013; Prausnitz et al., 2009; Quan et al., 2013; van der Maaden et al., 2014a) use much smaller needles (micron-scale). The length and shape of the microneedles and the application pressure determine the delivery depth.

Using these techniques differences in SC thickness and structure are less relevant, but differences in the skin morphology are important when comparing human skin with animal skin. Immunization sites with thicker viable epidermis and dermis are the most relevant sites to assure real intradermal immunization. Immunization on sites that have thin viable epidermis/dermis thickness will increase the chance of (partial) subcutaneous immunization. Data of dermis thickness is limited. Laurent et al. measured in human the epidermis-dermis thickness at different sites (Laurent et al., 2007). In humans, the usual site of id injection is the upper arm (deltoid area), the suprascapular region, the lower quadrant of the abdomen and the antero-lateral area of thigh (Laurent et al., 2007). These sites are chosen because they are close to the draining lymph nodes in axillary and neck areas, and their ease of access for vaccination. A study in 2007 (Laurent et al., 2007) in humans has shown that a skin penetration depth of $1.5 \mathrm{~mm}$ is appropriate for intradermal delivery. Delivery at this injection depth is not pain free because of the presence of nerve endings. In a clinical trial, $38-43 \%$ of the subjects reported pain, which is comparable to the i.m injection (LerouxRoels and Weber, 2013). Echographic measurements of the epidermis and dermis revealed that the total skin thickness depend on body site but that age, gender, ethnic origin and body mass index (BMI) did not affect the skin thickness at each measured body site (Laurent et al., 2007).

In animal studies, intradermal vaccines are delivered on the abdomen, the back or the ear. The total epidermis thickness of the back and abdomen are of the same range within female rats, mice and pigs (Bronaugh et al., 1983; Monteiro-Riviere et al., 1990). In male rats, the total epidermis thickness of the back is twice as thick as the abdomen (see Table 2). The ear is composed of mainly SC, viable epidermis and dermis. There is little loose tissue in the ear pinnae, hence subcutaneous delivery is not possible. The ear will separately be discussed further in this review.

Beside the epidermis and dermis thickness, elasticity of the skin has also to be considered when developing intradermal delivery systems. Because of the skin elasticity, force and speed of injection is important for efficient piercing, as well as the needle length. This was shown in a study by Verbaan et al. who showed that with $300 \mu \mathrm{m}$ microneedles, the skin was only pierced when an electric applicator, with a fixed adjusted speed, was used (Verbaan et al., 2008, 2007). This electric applicator was developed to prevent negative effects caused by the elasticity of the skin, like folding of the skin around the needle without penetration. Human skin has a high content of elastic tissue in the dermis compared to other mammalian skin (Starcher et al., 2005). The difference in elasticity between human and animal skin may be critical.

\section{The ear as a vaccination site in preclinical studies}

The most common site for topical and intradermal vaccination in animals is the abdomen or the back. These sites are easily accessible. Another popular site for vaccination in mice and rats is the ear. The choice for the ear as vaccination site is however not based on a better translation between man and animals but rather on anatomical and practical features of the ear.

The ear is a site that is less accessible to oral grooming preventing oral vaccination. It is a hairless surface and no shaving of the vaccination site is needed preventing possible abrasion and skin damage. As discussed before, even without abrasion, the shaving process is a stress factor that could influence the immune system. Moreover, injection into the ear dermis is mainly intradermally. Due to the lack of tissue under the skin dermis in the ear, there is no possibility for accidental subcutaneous injection in this site.

Studies with microneedle patch application in the ear showed excellent immune responses which were superior to i.m injections (Fernando et al., 2010) or ID injections in the ear (Carey et al., 2011). However, in case of i.m injections, most probably other draining lymph nodes are targeted and therefore a comparison should be done with care.

Several studies have been performed to compare the ear with the abdomen or back as immunization site in a same species. These studies resulted in divergent outcomes and give no answer to the question whether in animals, the skin of the ear is superior to the skin of the back or abdomen for translation studies to humans.

Belyakov et al. (2004) immunized the inner side of the ear (ventral side), abdomen and back of mice with an HIV peptide vaccine. The skin was pretreated with saline hydration and then with emery paper. A patch containing the vaccine solution is then applied on the pretreated skin. Comparable CTL responses were found after vaccination on the back and the abdomen. This immune response was however higher than the immune response induced after vaccination via the ear.

Naito et al. (2007), obtained better results with ear immunization as compared to immunization via the abdomen. The skin on the abdomen and the dorsal (outer) side of the ear was pretreated with a $70 \%$ ethanol swab before patch application containing ovalbumin as an antigen (Naito et al., 2007). With a prolonged topical application (up to $32 \mathrm{~h}$ ) procedure, good antibody responses even without the presence of cholera toxin (CT) were obtained. For the prolonged topical application, a gauze patch was used which was fixed with medical tape. Prolonged topical application in animal studies is, compared to human studies, difficult to perform. 
Animals are mostly anesthetized for cutaneous immunization enabling only limited application time.

van der Maaden et al. (2014b) confirmed with ovalbumin, higher immune responses with ear skin as compared to the ventral abdomen skin. When ovalbumin was applied on microneedle pretreated ear skin, an IgG titer was measured that was 36-fold higher than the $\operatorname{Ig} G$ response obtained via the ventral abdomen.

The studies referred to above, show that the ear is often but not always a superior site for topical immunization.

\section{Skin as an immunological organ}

After the first challenge of overcoming the skin barrier, the key players involved in shaping the most appropriate immune responses for that particular vaccine should be targeted. Several cell types that are present in the skin can contribute to the control of pathogens (Heath and Carbone, 2013). Vaccine induced immune responses are orchestrated by antigen presenting cells (APC). Therefore, we will describe below, how different APC in human skin relate to those in skin of mice and pigs. With respect to the subsequent $\mathrm{T}$ and $\mathrm{B}$ cell responses, these are only mentioned briefly for mice and humans, since little is known about these cells in the porcine situation.
The skin contains several types of APC that are difficult to distinguish. Based on mouse data, a new nomenclature for mononuclear phagocytes, comprising of dendritic cells, monocytes and macrophages, was suggested recently. The ontogeny of cells was used for primary classification and location, function and phenotype as secondary identification tools (Guilliams et al., 2014). In short, cells either can be of embryonic origin, or be derived from haematopoietic stem cells. With respect to the skin, mouse LC belong to the first group (Chorro et al., 2009). Dermal DCs belong to the lineage of haematopoietic stem cells, that can be further divided into monocyte-like cells, plasmacytoid DCs and pre-DCs. These findings seem to be quite conserved between mice and man (Haniffa et al., 2013, 2014; Malissen et al., 2014; Merad et al., 2013) and recent publications show that this will also likely translate to pigs, (Marquet et al., 2014; Summerfield et al., 2014)

An important point of consideration in vaccine development is the type of APC to target, since the diverse subtypes can induce different types of immune responses. Some general functions were found, for example $\mathrm{CD} 103^{+}$cells in mice and $\mathrm{CD} 141^{+}$cells in human are the subset best capable of inducing CD8 $\mathrm{T}$ cell responses, whereas the $C D 11 b^{+}$cells in mice and their human $C D 1 c^{+}$counterpart are strong activators of naïve helper T cells, as was excellently reviewed by Haniffa et al. (2013). The monocyte derived cells are

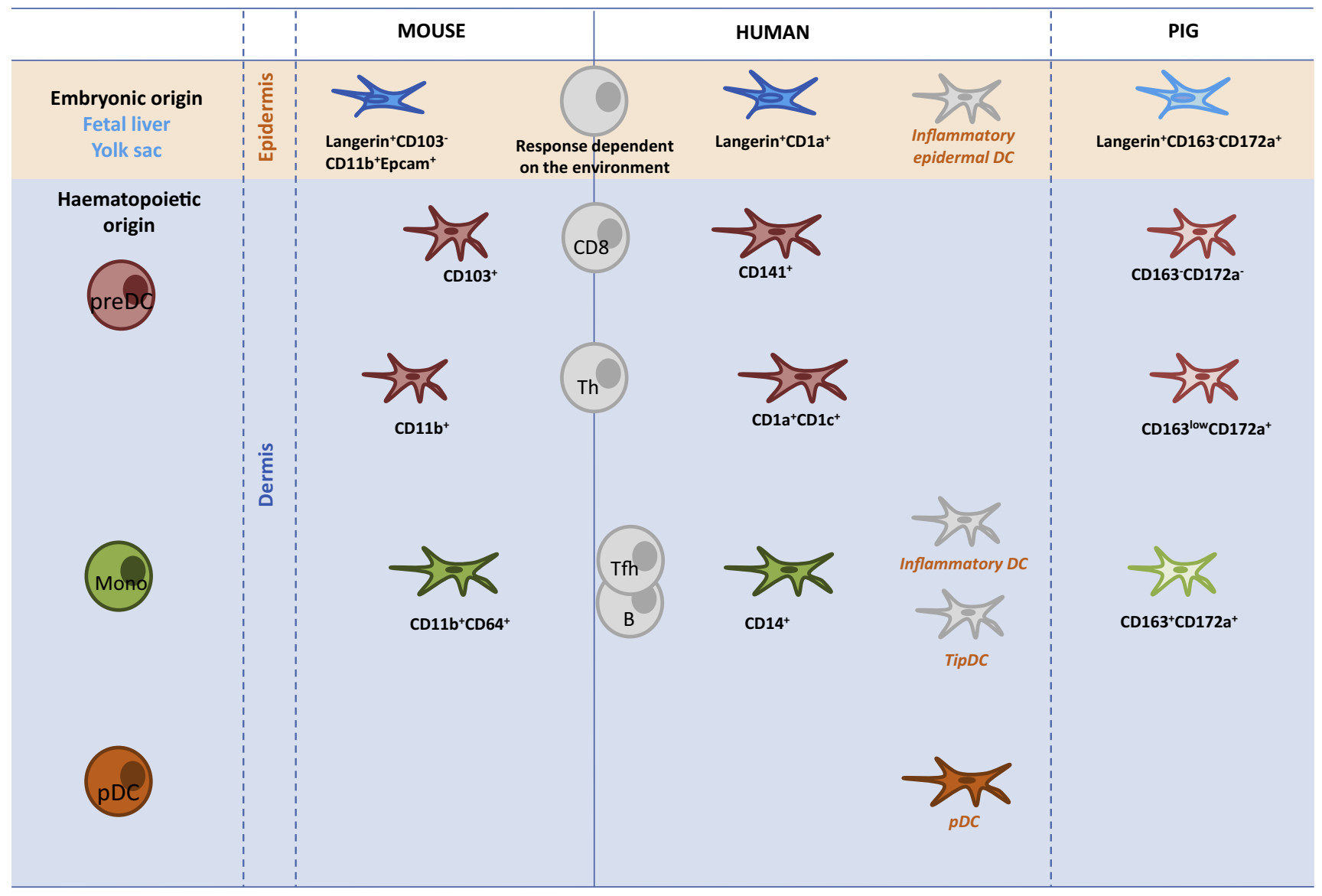

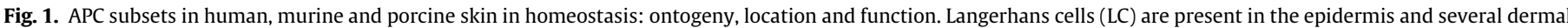

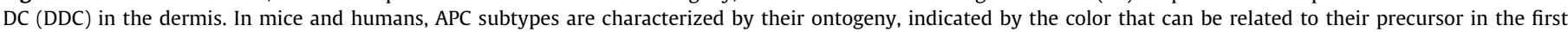

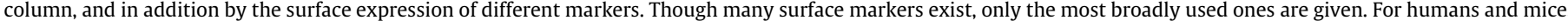

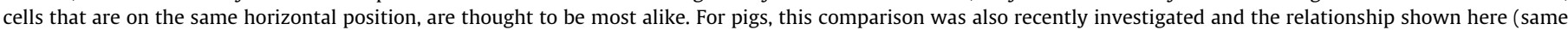

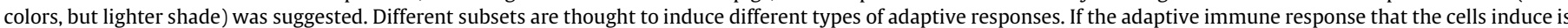

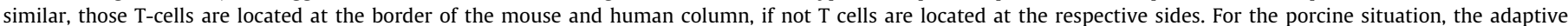

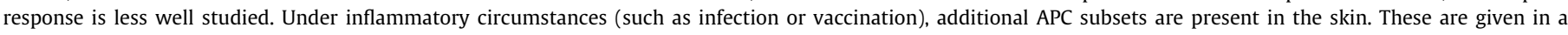

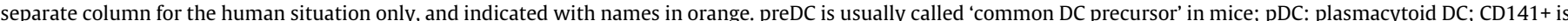

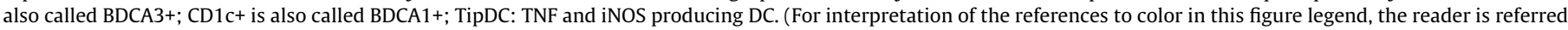
to the web version of this article.) 
strong inducers of follicular helper $\mathrm{T}$ cells and subsequent induction of humoral response, though this was mostly studied in the human situation. LC seem to be able to play various roles that is heavily depending on the environmental factors (Romani et al., 2012). Of note, though human and mouse APC subsets seem quite conserved, care should be taken in the extrapolation of murine findings to the human situation, since subsets resembling a certain subset in another species are alike but not identical (Bigley et al., 2014).

Regarding the situation in pigs, Marquet et al. divided the dermal DC in three different subsets based on the expression of CD163 and CD172 (Marquet et al., 2011) that were recently proposed to be included into a unified mammalian DC classification (Marquet et al., 2014) (Fig. 1).

Next to the cells present under steady state conditions, several additional APC subsets can be found in the skin when inflammatory conditions are induced, which also applies to vaccination. For example, pDC are not generally present in the skin under homeostatic conditions, but are recruited in case of an inflammatory response. Further, different types of inflammatory DC can be recruited from the blood (Haniffa et al., 2014) (Fig. 1, only given for the human situation).

Classically, upon vaccination through the skin, APC in the skin are studied and subsequently adaptive immune responses are studied elsewhere. Importantly, it has been shown that antigens can also be directly drained to lymph nodes (Bachmann and Jennings, 2010) and that lymph node resident APC can be important mediators of immune responses upon vaccination through the skin (Anandasabapathy et al., 2014). On the other hand, it was shown that skin resident memory $\mathrm{T}$ cells can be more important in protection from (re)infection, as compared to circulating memory $\mathrm{T}$ cells. The role of these cells was thoroughly reviewed (Heath and Carbone, 2013; Shin and Iwasaki, 2013). Both findings might lead to new vaccine strategies.

In addition, other tissue specific cells will play a role in shaping the environmental conditions. In the skin the keratinocytes play an important role herein, as they can produce anti-microbial peptides, cytokines and chemokines upon activation. Cytokines can activate APC and give direction to the type of immune response induced, whereas chemokines are involved in recruitment of immune cells, such as the inflammatory APC, to the skin. In addition, keratinocytes have been reported to function as non-professional antigen presenting cells themselves via surface expression of $\mathrm{MHC}$ class II molecules (Nestle et al., 2009).

In conclusion, current knowledge on mouse, human and pig skin immunology indicates care should be taken when translating results from animal experiments to the human situation, but several similarities exist. Interestingly in this respect is the recent increase in knowledge of the porcine skin immunology and the parallels with the human situation. Though tools for porcine studies are still limited compared to those for mice, they are steadily increasing (Summerfield et al., 2014).

\section{Adjuvants}

For the induction of strong and the appropriate type of immune response with topical or intradermal vaccination, strong stimuli are generally needed. Adjuvants can provide these signals and several adjuvants have been tested for topical application. However, licensed adjuvants, including alum, MF59 and AS03 (O'Hagan et al., 2013) can probably not be used for this administration route, because of their physical appearance, i.e. insoluble micrometer sized particles or oil in water emulsions. Adjuvants that are used experimentally for applications in the skin are ADP ribosylating exotoxins and TLR ligands.
The ADP ribosylating exotoxins, CT and LT, consist of 2 subunits, of which the B subunit binds to GM1 ganglioside receptors on the cell membrane of DC and the A subunit displays ADP-ribosyl transferase activity. They trigger both systemic and mucosal antibody responses in mice and humans and elicit strong $\mathrm{T}$ cell responses. The mechanism by which CT and LT exerts its adjuvant activity is not exactly known. Partidos et al. (2004) showed that CT induced apoptosis of keratinocytes when applied on intact skin. The apoptotic keratinocytes secrete cytokines that condition the LC to initiate $T$ cell responses in the lymph nodes. Another theory is that apoptosis partially disrupts the barrier function of the skin, resulting in a more rapid diffusion of molecules through the intercellular space of the epidermis (Partidos et al., 2004). CT is not only an adjuvant but also an antigen. The antibody response against cutaneous applied CT was investigated in $\mathrm{C} 57 \mathrm{BL} / 6, \mathrm{BalB} / \mathrm{C}, \mathrm{C} 3 \mathrm{H} / \mathrm{HeJ}$ and C3H/HeN mouse strains (Scharton-Kersten et al., 1999). When CT was topically applied on the ear of the mice, the IgG response was superior in $\mathrm{C} 57 \mathrm{BL} / 6$ mice followed by $\mathrm{BalB} / \mathrm{c}, \mathrm{C} 3 \mathrm{H} / \mathrm{HeJ}$ and $\mathrm{C} 3 \mathrm{H} / \mathrm{HeN}$. The differences between the strains was ascribed to the effects of the H-2 MHC genes. In the same study, it was found that mouse strains responded differently when another antigen was co-administered with CT. Only C57BL/6 and BaLB/c mice were able to induce an antibody response against diphtheria toxoid, whereas C57BL/6 mice were the only strain that could not mount a response to hen egg lysozyme. Moreover, several studies have reported these exotoxins to influence the quality of the immune response induced, ranging from a Th1 bias (Bal et al., 2010; Ding et al., 2009a, 2009b), to Th2 bias (Godefroy et al., 2003; Kahlon et al., 2003), or a mixed Th1/Th2 response (Hammond et al., 2001b; Scharton-Kersten et al., 2000) but also CD8 cytotoxic T cell response (Kahlon et al., 2003; Olvera-Gomez et al., 2012). Thus, adding CT or LT as an adjuvant will not only effect the strength of the response, but also the quality of the response and is not only dependent on the co-administered antigen but also on genetic background of mice. Therefore, several strains should be considered during early vaccine development.

In clinical trials, LT as an adjuvant, was only tested with antigens that were administered simultaneously via the i.m route (Frech et al., 2005). Elderly (>60 years) were vaccinated with seasonal influenza via the i.m route followed by the application of an LT patch distal to the vaccine injection site after mild abrasion of the skin. This group showed a significant increase in antibody titer as compared to the group that was vaccinated with only an influenza vaccine i.m injection. Interestingly, intradermal administration has been found to induce mucosal protection and these exotoxins are known to be strong mucosal adjuvants (Enioutina et al., 2000).

Besides the exotoxins CT and LT, TLR ligands are widely explored for cutaneous applications and are mostly associated with the induction of CD8 T-cells. TLRs are widely expressed by both immune cells, like DC and non-immune cells, such as keratinocytes. So far, 13 different TLR have been identified in humans and mice together. The majority of the TLRs both has a human and a mouse equivalent, but for example TLR 11, 12 and 13 are not present on human cells. TLRs can be expressed at the cell membrane (TLR1, 2, 4,5) or intracellular in endosomal compartments (TLR3, 7, 8, 9) (Lai and Gallo, 2008). Different cell types have a different expression panel of TLRs. It was demonstrated that LC express only virus-recognizing TLRs, whereas dermal DC express TLR recognizing both bacteria and viruses (van der Aar, 2007). Also expression patterns of mouse DC are not always comparable to TLRs expressed by human DC. Promising TLR ligands are CPG ODN that interacts with TLR9 (Cheng et al., 2014), Imiquimod that activates TLR7/8 (Li et al., 2014; Stein et al., 2014) and polyribosinic-polyribocytidylic acid (Poly I:C) (Weldon et al., 2012) that signals via TLR3. Many studies have been performed testing the efficacy of different combination 
of TLR ligands on the induction of specific immune responses both in mouse models and human skin models. In general, it can be concluded from these studies that TLR ligands have proven to be effective adjuvants that have the capacity to induce both cellular and humoral arm of the immune system. The adjuvant mechanism of TLR ligands is not clear yet. Cheng et al. (2014) speculate that topical CpG adjuvant induces keratinocyte as well as DC activation, multiplying immunogenic stimuli without promoting systemic inflammation. Depending on the type of immune response needed to be induced by the vaccine, it should be possible to combine TLR ligands in order to achieve activation of specific immune cells and induction of the right type of response, but more studies are warranted.

\section{Conclusion}

For cutaneous immunization, consistent and efficient delivery of vaccine is needed. The epidermis and dermis region of the skin is relatively thin with a SC barrier which is highly impermeable. For topical application, overcoming this SC is the main challenge. To this purpose, penetration enhancers and physical disruption of the SC enhance the penetration of antigens. Within a species, differences exist between the SC thicknesses at different sites. Choosing a site with the thinnest SC will shorten the pathway to the viable epidermis and dermis. With topical application, an alternative route to overcome the SC is the hair follicle. Animals have unlike human, abundant hair follicles. Therefore, hairless surfaces, such as the ear, are attractive sites for preclinical studies. For intradermal immunization, skin characteristics such as epidermis and dermis thickness and skin elasticity are factors that influence the delivery depth. In addition, anatomical and immunological differences are important factors for selecting proper animal models.

With respect to costs, knowledge and available tools, mice are interesting models. However the pig model also has other advantages compared to the mice, such as larger sample volume, possibility of repeated sampling and a closer resemblance to humans compared to mice, both genetically and physiologically. For example, the skin of pigs, like that of humans, is tightly attached to the subcutaneous connective tissue whereas rodent skin is only loosely connected. Several other characteristics mentioned earlier, including the density of hair follicles and thickness of the pig skin resemble the human situation.

Since the immunological knowledge and available analytical tools for the pig model are both increasing, the pig is an increasingly interesting preclinical model for cutaneous vaccination (Summerfield et al., 2014).

\section{References}

Agache, P., Agache, P.G., Humbert, P., 2004. Metrology of the Stratum Corneum. In: Philipp, M. (Ed.), Measuring the Skin. Non-invasive Investigations, Physiology, Normal Constants. Springer-Verlag, Berlin, pp. 101-111.

Anandasabapathy, N., Feder, R., Mollah, S., Tse, S.W., Longhi, M.P., Mehandru, S., Matos, I., Cheong, C., Ruane, D., Brane, L., Teixeira, A., Dobrin, J., Mizenina, O., Park, C.G., Meredith, M., Clausen, B.E., Nussenzweig, M.C., Steinman, R.M., 2014. Classical Flt3L-dependent dendritic cells control immunity to protein vaccine. J. Exp. Med. 211, 1875-1891.

Bachmann, M.F., Jennings, G.T., 2010. Vaccine delivery: a matter of size, geometry, kinetics and molecular patterns. Nat. Rev. Immunol. 10, 787-796.

Bal, S.M., Ding, Z., Kersten, G.F., Jiskoot, W., Bouwstra, J.A., 2010. Microneedle-based transcutaneous immunisation in mice with $\mathrm{N}$-trimethyl chitosan adjuvanted diphtheria toxoid formulations. Pharm. Res. 27, 1837-1847.

Behrens, R.H., Cramer, J.P., Jelinek, T., Shaw, H., von Sonnenburg, F., Wilbraham, D., Weinke, T., Bell, D.J., Asturias, E., Pauwells, H.L., Maxwell, R., Paredes-Paredes, M., Glenn, G.M., Dewasthaly, S., Stablein, D.M., Jiang, Z.D., Dupont, H.L., 2014. Efficacy and safety of a patch vaccine containing heat-labile toxin from Escherichia coli against travellers' diarrhoea: a phase 3, randomised, doubleblind, placebo-controlled field trial in travellers from Europe to Mexico and Guatemala. Lancet. Infect. Dis 14, 197-204.

Beignon, A.S., Briand, J.P., Muller, S., Partidos, C.D., 2001. Immunization onto bare skin with heat-labile enterotoxin of Escherichia coli enhances immune responses to coadministered protein and peptide antigens and protects mice against lethal toxin challenge. Immunology 102, 344-351.

Belyakov, I.M., Hammond, S.A., Ahlers, J.D., Glenn, G.M., Berzofsky, J.A., 2004 Transcutaneous immunization induces mucosal CTLs and protective immunity by migration of primed skin dendritic cells. J. Clin. Investig. 113, 998-1007.

Benson, H.A., 2005. Transdermal drug delivery: penetration enhancement techniques. Curr. Drug Deliv. 2, 23-33.

Bigley, V., McGovern, N., Milne, P., Dickinson, R., Pagan, S., Cookson, S., Haniffa, M., Collin, M., 2014. Langerin-expressing dendritic cells in human tissues are related to $\mathrm{CD} 1 \mathrm{c}^{+}$dendritic cells and distinct from Langerhans cells and CD141high XCR1+ dendritic cells. Journal of leukocyte biology.

Bohling, A., Bielfeldt, S., Himmelmann, A., Keskin, M., Wilhelm, K.P., 2014 Comparison of the stratum corneum thickness measured in vivo with confocal Raman spectroscopy and confocal reflectance microscopy. Skin Res. Technol. 20, 50-57.

Bos, J.D., Meinardi, M.M., 2000. The 500 Dalton rule for the skin penetration of chemical compounds and drugs. Exp. Dermatol. 9, 165-169.

Bouwstra, J.A., Gooris, G.S., van der Spek, J.A., Bras, W., 1991. Structural investigations of human stratum corneum by small-angle X-ray scattering. J. Invest. Dermatol. 97, 1005-1012.

Bouwstra, J.A., Gooris, G.S., van der Spek, J.A., Lavrijsen, S., Bras, W., 1994. The lipid and protein structure of mouse stratum corneum: a wide and small angle diffraction study. Biochim. Biophys. Acta 1212, 183-192.

Bouwstra, J.A., Gooris, G.S., Bras, W., Downing, D.T., 1995. Lipid organization in pig stratum corneum. J. Lipid Res. 36, 685-695.

Bouwstra, J.A de Graaff, A Gooris, G.S Nijsse, J. Wiechers, JW van Aelst, A.C., 2003. Water distribution and related morphology in human stratum corneum at different hydration levels. J. Invest. Dermatol. 120, 750-758.

Bronaugh, R.L., Stewart, R.F., Congdon, E.R., 1982. Methods for in vitro percutaneous absorption studies II. Animal models for human skin. Toxicol. Appl. Pharmacol. $62,481-488$

Bronaugh, R.L., Stewart, R.F., Congdon, E.R., 1983. Differences in permeability of rat skin related to sex and body site. J. Soc. Cosmet. Chem. 34, 127-135.

Carey, J.B., Pearson, F.E., Vrdoljak, A., McGrath, M.G., Crean, A.M., Walsh, P.T., Doody, T., O’Mahony, C., Hill, A.V., Moore, A.C., 2011. Microneedle array design determines the induction of protective memory CD8+ $T$ cell responses induced by a recombinant live malaria vaccine in mice. PLoS ONE 6, e22442.

Caussin, J., Gooris, G.S., Janssens, M., Bouwstra, J.A., 2008. Lipid organization in human and porcine stratum corneum differs widely, while lipid mixtures with porcine ceramides model human stratum corneum lipid organization very closely. Biochim. Biophys. Acta 1778, 1472-1482.

Cevc, G., Blume, G., 1992. Lipid vesicles penetrate into intact skin owing to the transdermal osmotic gradients and hydration force. Biochim. Biophys. Acta $1104,226-232$.

Cevc, G., Schatzlein, A., Richardsen, H., 2002. Ultradeformable lipid vesicles can penetrate the skin and other semi-permeable barriers unfragmented. Evidence from double label CLSM experiments and direct size measurements. Biochim. Biophys. Acta 1564, 21-30.

Chantasart, D., Li, S.K., 2012. Structure enhancement relationship of chemica penetration enhancers in drug transport across the stratum corneum. Pharmaceutics 4, 71-92.

Cheng, W.K., Wee, K., Kollmann, T.R., Dutz, J.P., 2014. Topical CpG adjuvantation of a protein-based vaccine induces protective immunity to Listeria monocytogenes. Clinical Vaccine Immunology: CVI 21, 329-339.

Chorro, L., Sarde, A., Li, M., Woollard, K.J., Chambon, P., Malissen, B., Kissenpfennig A., Barbaroux, J.B., Groves, R., Geissmann, F., 2009. Langerhans cell (LC) proliferation mediates neonatal development, homeostasis, and inflammation-associated expansion of the epidermal LC network. J. Exp. Med. 206, 3089-3100.

Combadiere, B., Vogt, A., Mahe, B., Costagliola, D., Hadam, S., Bonduelle, O., Sterry, W., Staszewski, S., Schaefer, H., van der Werf, S., Katlama, C., Autran, B., BlumePeytavi, U., 2010. Preferential amplification of CD8 effector-T cells after transcutaneous application of an inactivated influenza vaccine: a randomized phase I trial. PLoS ONE 5, e10818.

de Jager, M., Groenink, W., Bielsa i Guivernau, R., Andersson, E., Angelova, N., Ponec M., Bouwstra, J., 2006. A novel in vitro percutaneous penetration model: evaluation of barrier properties with p-aminobenzoic acid and two of its derivatives. Pharm. Res. 23, 951-960.

Ding, Z., Van Riet, E., Romeijn, S., Kersten, G.F., Jiskoot, W., Bouwstra, J.A., 2009a. Immune modulation by adjuvants combined with diphtheria toxoid administered topically in BALB/c mice after microneedle array pretreatment. Pharm. Res. 26, 1635-1643.

Ding, Z., Verbaan, F.J., Bivas-Benita, M., Bungener, L., Huckriede, A., van den Berg, D.J., Kersten, G., Bouwstra, J.A., 2009b. Microneedle arrays for the transcutaneous immunization of diphtheria and influenza in BALB/c mice. J. Control. Release: Off. J. Control. Release Soc. 136, 71-78.

Egawa, M., Hirao, T., Takahashi, M., 2007. In vivo estimation of stratum corneum thickness from water concentration profiles obtained with Raman spectroscopy. Acta Derm-Venereol. 87, 4-8.

Enioutina, E.Y., Visic, D., Daynes, R.A., 2000. The induction of systemic and mucosal immune responses to antigen-adjuvant compositions administered into the skin: alterations in the migratory properties of dendritic cells appears to be important for stimulating mucosal immunity Vaccine 18 2753-2767.

Etchart, N., Hennino, A., Friede, M., Dahel, K., Dupouy, M., Goujon-Henry, C., Nicolas, J.F., Kaiserlian, D., 2007. Safety and efficacy of transcutaneous vaccination using 
a patch with the live-attenuated measles vaccine in humans. Vaccine 25, 68916899.

Fairley, J.A., Rasmussen, J.E., 1983. Comparison of stratum corneum thickness in children and adults. J. Am. Acad. Dermatol. 8, 652-654.

Fan, H., Lin, Q., Morrissey, G.R., Khavari, P.A., 1999. Immunization via hair follicles by topical application of naked DNA to normal skin. Nat. Biotechnol. 17, 870872 .

Fernando, G.J., Chen, X., Prow, T.W., Crichton, M.L., Fairmaid, E.J., Roberts, M.S. Frazer, I.H., Brown, L.E., Kendall, M.A., 2010. Potent immunity to low doses of influenza vaccine by probabilistic guided micro-targeted skin delivery in a mouse model. PLoS ONE 5, e10266.

Fluhr, J.W., Lachmann, N., Baudouin, C., Msika, P., Darlenski, R., De Belilovsky, C., Bosssert, J., Colomb, E., Burdin, B., Haftek, M., 2014. Development and organization of human stratum corneum after birth. Electron microscopy isotropy score and immunocytochemical corneocyte labelling as epidermal maturation's markers in infancy. Brit. J. Dermatol.

Foldvari, M., Gesztes, A., Mezei, M., 1990. Dermal drug delivery by liposome encapsulation: clinical and electron microscopic studies. J. Microencapsul. 7 479-489.

Frech, S.A., Kenney, R.T., Spyr, C.A., Lazar, H., Viret, J.F., Herzog, C., Gluck, R., Glenn, G.M., 2005. Improved immune responses to influenza vaccination in the elderly using an immunostimulant patch. Vaccine 23, 946-950.

Glenn, G.M., Scharton-Kersten, T., Vassell, R., Mallett, C.P., Hale, T.L., Alving, C.R, 1998. Transcutaneous immunization with cholera toxin protects mice against lethal mucosal toxin challenge. J. Immunol. 161, 3211-3214.

Glenn, G.M., Scharton-Kersten, T., Alving, C.R., 1999a. Advances in vaccine delivery: transcutaneous immunisation. Expert Opin. Investig. Drugs 8, 797-805.

Glenn, G.M., Scharton-Kersten, T., Vassell, R., Matyas, G.R., Alving, C.R., 1999b. Transcutaneous immunization with bacterial ADP-ribosylating exotoxins as antigens and adjuvants. Infect. Immun. 67, 1100-1106.

Glenn, G.M., Taylor, D.N., Li, X., Frankel, S., Montemarano, A., Alving, C.R., 2000 Transcutaneous immunization: a human vaccine delivery strategy using a patch. Nat. Med. 6, 1403-1406.

Godefroy, S., Goestch, L., Plotnicky-Gilquin, H., Nguyen, T.N., Schmitt, D., Staquet M.J., Corvaia, N., 2003. Immunization onto shaved skin with a bacterial enterotoxin adjuvant protects mice against respiratory syncytial virus (RSV). Vaccine 21, 1665-1671.

Guilliams, M., Ginhoux, F., Jakubzick, C., Naik, S.H., Onai, N., Schraml, B.U., Segura, E. Tussiwand, R., Yona, S., 2014. Dendritic cells, monocytes and macrophages: unified nomenclature based on ontogeny. Nat. Rev. Immunol. 14, 571-578.

Gupta, P.N., Mishra, V., Rawat, A., Dubey, P., Mahor, S., Jain, S., Chatterji, D.P., Vyas S.P., 2005a. Non-invasive vaccine delivery in transfersomes, niosomes and liposomes: a comparative study. Int. J. Pharm. 293, 73-82.

Gupta, P.N., Mishra, V., Singh, P., Rawat, A., Dubey, P., Mahor, S., Vyas, S.P., 2005b. Tetanus toxoid-loaded transfersomes for topical immunization. J. Pharm. Pharmacol. 57, 295-301.

Hammond, S.A., Guebre-Xabier, M., Yu, J., Glenn, G.M., 2001a. Transcutaneous immunization: an emerging route of immunization and potent immunostimulation strategy. Crit. Rev. Ther. Drug Carrier Syst. 18, 503-526.

Hammond, S.A., Walwender, D., Alving, C.R., Glenn, G.M., 2001b. Transcutaneous immunization: T cell responses and boosting of existing immunity. Vaccine 19 $2701-2707$.

Haniffa, M., Collin, M., Ginhoux, F., 2013. Ontogeny and functional specialization of dendritic cells in human and mouse. Adv. Immunol. 120, 1-49.

Haniffa, M., Gunawan, M., Jardine, L., 2014. Human skin dendritic cells in health and disease. J. Dermatol. Sci.

Heath, W.R., Carbone, F.R., 2013. The skin-resident and migratory immune system in steady state and memory: innate lymphocytes, dendritic cells and $\mathrm{T}$ cells. Nat. Immunol. 14, 978-985.

Holbrook, K.A., Odland, G.F., 1974. Regional differences in the thickness (cell layers) of the human stratum corneum: an ultrastructural analysis. J. Invest. Dermatol. $62,415-422$.

Honeywell-Nguyen, P.L., Wouter Groenink, H.W., de Graaff, A.M., Bouwstra, J.A. 2003. The in vivo transport of elastic vesicles into human skin: effects of occlusion, volume and duration of application. J. Control. Release: Off. J. Control. Release Soc. 90, 243-255.

Huzaira, M., Rius, F., Rajadhyaksha, M., Anderson, R.R., Gonzalez, S., 2001. Topographic variations in normal skin, as viewed by in vivo reflectance confocal microscopy. J. Invest. Dermatol. 116, 846-852.

Jacobi, U., Kaiser, M., Toll, R., Mangelsdorf, S., Audring, H., Otberg, N., Sterry, W., Lademann, J., 2007. Porcine ear skin: an in vitro model for human skin. Skin Res. Technol. 13, 19-24.

Jung, S., Otberg, N., Thiede, G., Richter, H., Sterry, W., Panzner, S., Lademann, J., 2006 Innovative liposomes as a transfollicular drug delivery system: penetration into porcine hair follicles. J. Invest. Dermatol. 126, 1728-1732.

Kahlon, R., Hu, Y., Orteu, C.H., Kifayet, A., Trudeau, J.D., Tan, R., Dutz, J.P., 2003. Optimization of epicutaneous immunization for the induction of CTL. Vaccine $21,2890-2899$

Kim, Y.C., Park, J.H., Prausnitz, M.R., 2012. Microneedles for drug and vaccine delivery. Adv. Drug Deliv. Rev. 64, 1547-1568.

Koehler, M.J., Vogel, T., Elsner, P., Konig, K., Buckle, R., Kaatz, M., 2010. In vivo measurement of the human epidermal thickness in different localizations by multiphoton laser tomography. Skin Res. Technol. 16, 259-264.

Kommareddy, S., Baudner, B.C., Bonificio, A., Gallorini, S., Palladino, G., Determan, A.S., Dohmeier, D.M., Kroells, K.D., Sternjohn, J.R., Singh, M., Dormitzer, P.R. Hansen, K.J., O’Hagan, D.T., 2013. Influenza subunit vaccine coated microneedle patches elicit comparable immune responses to intramuscular injection in guinea pigs. Vaccine 31, 3435-3441.

Koutsonanos, D.G., Compans, R.W., Skountzou, I., 2013. Targeting the skin for microneedle delivery of influenza vaccine. Adv. Exp. Med. Biol. 785, 121-132.

Lai, Y., Gallo, R.L., 2008. Toll-like receptors in skin infections and inflammatory diseases. Infect. Disord. Drug Targets 8, 144-155.

Lane, M.E., 2013. Skin penetration enhancers. Int. J. Pharm. 447, 12-21.

Laurent, A., Mistretta, F., Bottigioli, D., Dahel, K., Goujon, C., Nicolas, J.F., Hennino, A. Laurent, P.E., 2007. Echographic measurement of skin thickness in adults by high frequency ultrasound to assess the appropriate microneedle length for intradermal delivery of vaccines. Vaccine 25, 6423-6430.

Leroux-Roels, I., Weber, F., 2013. Intanza ((R)) 9 microg intradermal seasonal influenza vaccine for adults 18 to 59 years of age. Human Vaccines Immunother. 9, 115-121.

Li, N., Peng, L.H., Chen, X., Zhang, T.Y., Shao, G.F., Liang, W.Q., Gao, J.Q., 2014 Antigen-loaded nanocarriers enhance the migration of stimulated Langerhans cells to draining lymph nodes and induce effective transcutaneous immunization. Nanomed. Nanotechnol. Biol. Med. 10, 215-223.

Mahe, B., Vogt, A., Liard, C., Duffy, D., Abadie, V., Bonduelle, O., Boissonnas, A., Sterry, W., Verrier, B., Blume-Peytavi, U., Combadiere, B., 2009. Nanoparticle-based targeting of vaccine compounds to skin antigen-presenting cells by hair follicles and their transport in mice. J. Invest. Dermatol. 129, 1156-1164.

Malissen, B., Tamoutounour, S., Henri, S., 2014. The origins and functions of dendritic cells and macrophages in the skin. Nat. Rev. Immunol. 14, 417-428.

Marquet, F., Bonneau, M., Pascale, F., Urien, C., Kang, C., Schwartz-Cornil, I., Bertho, N., 2011. Characterization of dendritic cells subpopulations in skin and afferent lymph in the swine model. PLoS ONE 6, e16320.

Marquet, F., Vu Manh, T.P., Maisonnasse, P., Elhmouzi-Younes, J., Urien, C., Bouguyon, E., Jouneau, L., Bourge, M., Simon, G., Ezquerra, A., Lecardonnel, J., Bonneau, M. Dalod, M., Schwartz-Cornil, I., Bertho, N., 2014. Pig skin includes dendritic cell subsets transcriptomically related to human CD1a and CD14 dendritic cells presenting different migrating behaviors and $\mathrm{T}$ cell activation capacities. J. Immunol. 193, 5883-5893.

Merad, M., Sathe, P., Helft, J., Miller, J., Mortha, A., 2013. The dendritic cell lineage: ontogeny and function of dendritic cells and their subsets in the steady state and the inflamed setting. Annu. Rev. Immunol. 31, 563-604.

Meyer, W., 2009. Hair follicles in domesticated mammals with comparison to laboratory animals and humans. In: Mecklenburg, L., Linek, M., Tobin, D.J. (Eds.), Hair Loss Disorders in Domestic Animals. John Wiley \& Sons, pp. 43-62.

Mezei, M., Gulasekharam, V., 1980. Liposomes-a selective drug delivery system for the topical route of administration. Lotion dosage form. Life Sci. 26, 1473-1477.

Mishra, D., Dubey, V., Asthana, A., Saraf, D.K., Jain, N.K., 2006. Elastic liposomes mediated transcutaneous immunization against Hepatitis B. Vaccine.

Moghadam, S.H., Saliaj, E., Wettig, S.D., Dong, C., Ivanova, M.V., Torin Huzil, J., Foldvari, M., 2013. Effect of chemical permeation enhancers on stratum corneum barrier lipid organizational structure and interferon alpha permeability. Mol. Pharm. 10, 2248-2260.

Monteiro-Riviere, N.A., 2010. Anatomical factors affecting barrier function. In: Wilhelm, K.P., Zhai, H., Maibach, H. (Eds.), Dermatotoxicology, 7th edition ed, pp. 39-47.

Monteiro-Riviere, N.A., Bristol, D.G., Manning, T.O., Rogers, R.A., Riviere, J.E., 1990 Interspecies and interregional analysis of the comparative histologic thickness and laser Doppler blood flow measurements at five cutaneous sites in nine species. J. Invest. Dermatol. 95, 582-586.

Naito, S., Maeyama, J., Mizukami, T., Takahashi, M., Hamaguchi, I., Yamaguchi, K. 2007. Transcutaneous immunization by merely prolonging the duration of antigen presence on the skin of mice induces a potent antigen-specific antibody response even in the absence of an adjuvant. Vaccine 25, 8762-8770.

Nestle, F.O., Di Meglio, P., Qin, J.Z., Nickoloff, B.J., 2009. Skin immune sentinels in health and disease. Nat. Rev. Immunol. 9, 679-691.

Nikolovski, J., Stamatas, G.N., Kollias, N., Wiegand, B.C., 2008. Barrier function and water-holding and transport properties of infant stratum corneum are different from adult and continue to develop through the first year of life. J. Invest. Dermatol. 128, 1728-1736.

O'Hagan, D.T., Ott, G.S., Nest, G.V., Rappuoli, R., Giudice, G.D., 2013. The history of MF59((R)) adjuvant: a phoenix that arose from the ashes. Expert Rev. Vaccines $12,13-30$.

Olvera-Gomez, I., Hamilton, S.E., Xiao, Z., Guimaraes, C.P., Ploegh, H.L., Hogquist, K.A., Wang, L., Jameson, S.C., 2012. Cholera toxin activates nonconventional adjuvant pathways that induce protective CD8 T-cell responses after epicutaneous vaccination. Proc. Natl. Acad. Sci. U.S.A. 109, 2072-2077.

Partidos, C.D., Beignon, A.S., Briand, J.P., Muller, S., 2004. Modulation of immune responses with transcutaneously deliverable adjuvants. Vaccine 22, 2385-2390.

Ploin, D., Schwarzenbach, F., Dubray, C., Nicolas, J.F., Goujon, C., Trong, M.D. Laurent, P.E., 2011. Echographic measurement of skin thickness in sites suitable for intradermal vaccine injection in infants and children. Vaccine 29, 84388442.

Prausnitz, M.R., Mikszta, J.A., Cormier, M., Andrianov, A.K., 2009. Microneedle-based vaccines, Curr. Top. Microbiol. Immunol. 333, 369-393.

Quan, F.S., Kim, Y.C., Song, J.M., Hwang, H.S., Compans, R.W., Prausnitz, M.R., Kang, S.M., 2013. Long-term protective immunity from an influenza virus-like particle vaccine administered with a microneedle patch. Clin. Vaccine Immunol.: CVI 20, 1433-1439.

Rissmann, R., Oudshoorn, M.H., Hennink, W.E., Ponec, M., Bouwstra, J.A., 2009. Skin barrier disruption by acetone: observations in a hairless mouse skin model. Arch. Dermatol. Res. 301, 609-613. 
Robertson, K., Rees, J.L., 2010. Variation in epidermal morphology in human skin at different body sites as measured by reflectance confocal microscopy. Acta Derm.-Venereol. 90, 368-373.

Romani, N., Brunner, P.M., Stingl, G., 2012. Changing views of the role of Langerhans cells. J. Invest. Dermatol. 132, 872-881.

Ruutu, M.P., Chen, X., Joshi, O., Kendall, M.A., Frazer, I.H., 2011. Increasing mechanical stimulus induces migration of Langerhans cells and impairs the immune response to intracutaneously delivered antigen. Exp. Dermatol. 20, 534-536.

Sandby-Moller, J., Poulsen, T., Wulf, H.C., 2003. Epidermal thickness at different body sites: relationship to age, gender, pigmentation, blood content, skin type and smoking habits. Acta Derm.-Venereol. 83, 410-413.

Sato, K., Sugibayashi, K., Morimoto, Y., 1991. Species differences in percutaneous absorption of nicorandil. J. Pharm. Sci. 80, 104-107.

Scharton-Kersten, T., Glenn, G.M., Vassell, R., Yu, J., Walwender, D., Alving, C.R., 1999. Principles of transcutaneous immunization using cholera toxin as an adjuvant. Vaccine 17 (Suppl 2), S37-43.

Scharton-Kersten, T., Yu, J., Vassell, R., O’Hagan, D., Alving, C.R., Glenn, G.M., 2000. Transcutaneous immunization with bacterial ADP-ribosylating exotoxins, subunits, and unrelated adjuvants. Infect. Immun. 68, 5306-5313.

Shin, H., Iwasaki, A., 2013. Tissue-resident memory T cells. Immunol. Rev. 255, 165181.

Simon, G.A., Maibach, H.I., 2000. The pig as an experimental animal model of percutaneous permeation in man: qualitative and quantitative observations-an overview. Skin Pharmacol. Appl. Skin Physiol. 13, 229-234.

Starcher, B., Aycock, R.L., Hill, C.H., 2005. Multiple roles for elastic fibers in the skin. J. Histochem. Cytochem.: Off. J. Histochem. Soc. 53, 431-443.

Steffen, R., Cramer, J.P., Burchard, G., Jelinek, T., Schwarz, U., Ramdas, P., Chatterjee, S., Jiang, Z.D., DuPont, H.L., Dewasthaly, S., Westritschnig, K., Behrens, R.H., 2013. Efficacy of a travelers' diarrhea vaccine system in travelers to India. J. Travel Med. 20, 374-379.

Stein, P., Gogoll, K., Tenzer, S., Schild, H., Stevanovic, S., Langguth, P., Radsak, M.P., 2014. Efficacy of imiquimod-based transcutaneous immunization using a nanodispersed emulsion gel formulation. PLoS ONE 9, e102664.
Summerfield, A., Meurens, F., Ricklin, M.E., 2014. The immunology of the porcine skin and its value as a model for human skin. Mol. Immunol.

Swindle, M.M., 2008. Porcine integumentary system models: part: Dermal toxicology.

van der Maaden, K., Trietsch, S.J., Kraan, H., Varypataki, E.M., Romeijn, S., Zwier, R., van der Linden, H.J., Kersten, G., Hankemeier, T., Jiskoot, W., Bouwstra, J., 2014a. Novel hollow microneedle technology for depth-controlled microinjectionmediated dermal vaccination: a study with polio vaccine in rats. Pharm. Res.

van der Maaden, K., Varypataki, E.M., Yu, H., Romeijn, S., Jiskoot, W., Bouwstra, J. 2014b. Parameter optimization toward optimal microneedle-based dermal vaccination. Eur. J. Pharm. Sci.: Off. J. Eur. Fed. Pharm. Sci.

van Smeden, J., Janssens, M., Gooris, G.S., Bouwstra, J.A., 2014. The important role of stratum corneum lipids for the cutaneous barrier function. Biochim. Biophys. Acta 1841, 295-313.

Verbaan, F.J., Bal, S.M., van den Berg, D.J., Groenink, W.H., Verpoorten, H., Luttge, R., Bouwstra, J.A., 2007. Assembled microneedle arrays enhance the transport of compounds varying over a large range of molecular weight across human dermatomed skin. J. Control. Release: Off. J. Control. Release Soc. 117, 238-245.

Verbaan, F.J., Bal, S.M., van den Berg, D.J., Dijksman, J.A., van Hecke, M., Verpoorten, H., van den Berg, A., Luttge, R., Bouwstra, J.A., 2008. Improved piercing of microneedle arrays in dermatomed human skin by an impact insertion method. J. Control. Release: Off. J. Control. Release Soc. 128, 80-88.

Vogt, A., Combadiere, B., Hadam, S., Stieler, K.M., Lademann, J., Schaefer, H., Autran, B., Sterry, W., Blume-Peytavi, U., 2006. $40 \mathrm{~nm}$, but not 750 or $1500 \mathrm{~nm}$, nanoparticles enter epidermal CD1a+ cells after transcutaneous application on human skin. J. Invest. Dermatol. 126, 1316-1322.

Weldon, W.C., Zarnitsyn, V.G., Esser, E.S., Taherbhai, M.T., Koutsonanos, D.G. Vassilieva, E.V., Skountzou, I., Prausnitz, M.R., Compans, R.W., 2012. Effect of adjuvants on responses to skin immunization by microneedles coated with influenza subunit vaccine. PLoS ONE 7, e41501.

Williams, A.C., Barry, B.W., 1992. Skin absorption enhancers. Crit. Rev. Ther. Drug Carrier Syst. 9, 305-353. 